\title{
NEUROCYSTICERCOSIS: TREATMENT WITH ALBENDAZOLE AND DEXTROCHLOROPHENIRAMINE (PRELIMINARY REPORT).
}

\author{
Svellana AGAPEJEV(1), Domingos Alves MEIRA ${ }^{21}$, Benedito BARRAVIERA ${ }^{21}$, Jussara Marcondes MACHAI)O(2),

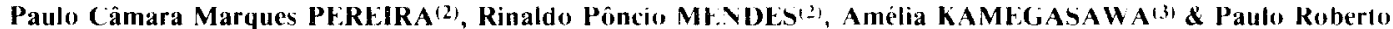 \\ CURI'i
}

KEY WORDS: Neurocysticercosis: Albendazole; Dextrochloropheniramine;

Treatment.

The clinical variability of neurocysticercosis is due to a series of factors such as number, location, form, dimensions and stage of development of the parasite, the nature of its action on the organism and the individual immunological response of the host $3,4,6$. Thus, diagnosis is very difficult, especially in not highly endemic areas or in regions were laboratory support is lacking. Another important feature to be considered in the approach to neurocysticercosis is the lack of an alternative program of antiparasitic treatment. The high coast of treatment with praziquantel and the side effects of corticosteroidss are factors that have led to the search for new treatment programs.

Albendazole, a drug belonging to the benzimidazole group, is characterized by high therapeutic indices as a polyvalent antihelmintic agent ${ }^{\star}$ and with efficacy in patients with hydatic cysts? Dextrochloropheniramine is a potent anti-histaminic with good penetration in the central nervous system which acts on cerebral histamine receptors by a competitive mechanism².

The objective of the present research was to evaluate for the first time the therapeutic action of albendazole in combination with dextrochloropheniramine in patients with cysticercosis.

Fourty patients were treated on the Infectious and Parasitic Diseases and on the Neurology ward of the University Hospital, Faculty of Medicine of Botucatu, UNESP, from September 1984 to December 1987. Three clinical treatment groups were formed:

Group I: 10 to $15 \mathrm{mg} / \mathrm{kg} / \mathrm{day}$ of albendazole by oral route in two series of 28 days each;

Group II: 15 to $25 \mathrm{mg} / \mathrm{kg} /$ day, in three series of 21 days each;

Group III: 15 to $30 \mathrm{mg} / \mathrm{kg} / \mathrm{day}$, in two series of 21 and 30 days. All of the patients in the three groups also received uninterruptedly $18 \mathrm{mg} / \mathrm{day}$ dextrochloropheniramine administered orally, during and 4 to 6 months after the end of treatment.

All patients were evaluated by clinical examination and laboratory tests, during and immediatelly after, as well as 5 to 20 months after the end of treatment. All potentially fertile women were submitted to pregnancy tests before and during treatment with albendazole. The ethical norms of Helsinki

(1) Department of Neurology and Psychiatry, Faculty of Medicine of Botucatu (UNESP), Botucatu, São Paulo, Brazil..

(2) Department of Infectious and Parasitic Diseases, Dermatology and Radiology, Faculty of Medicine of Botucatu (UNESP), Botucatu, São Paulo, Brazil.

(3) Department of Ophthalmology and Otorhinolaryngology, Faculty of Medicine of Botucatu (UNESP), Botucatu, São Paulo, Brazil.

(4) Statistician, Faculty of Medicine of Botucatu (UNESP), Botucatu, São Paulo, Brazil.

Address for correspondence: Dra. Svetlana Agapejev. Departamento de Neurologia e Psiquiatria da Faculdade de Medicina de Botucatu (UNESP). CEP 18610, Botucatu, SP, Brasil. 
AGAPEJEV, S.; MEIRA, D.A.; BARRAVIERA, B.; MACHADO, J.M.; PEREIRA, P.C.M.; MENDES, R.P.; KAMEGASAWA, A. \& CURI, P.R. - Neurocysticercosis: treatment with albendazole and dextrochloropheniramine. (Preliminary report). Rev. Inst. Med, trop. Sào Paulo, 30(5):387-389, 1988.

Treaty were strictly obeyed for all of the participants in the three groups.

The following parameters were used to evaluate the treatment schedule used:

Clinical: remission of clinical manifestations, as indicated by the disappearance of symptoms, by the improve of the neurological examination and of the quality of life. The latter was also evaluated quantitatively by attributing scores to the different types, as follows: death $=0$; great limitations $=1$; medium limitations $=2$; small limitations $=3$ and normal life $=4$

Laboratory tests: realized to detect some side effects of the drug: complete hemogram; measurements of blood glucose, amino transferase, bilirubins, proteins, mucoproteins, uric acid; urea, creatinine and electrolytes $\left(\mathrm{Ca}+{ }^{+}, \mathrm{Na}+\right.$ and $\left.\mathrm{K}^{+}\right)$. Fecal parasitology and urinalysis were also included in the protocol.

Cerebrospinal fluid (CSF): normalization or at least improve of the CSF analysis by the realization of tests for the presence of anticysticercum antibodies, glucose, protein and chloride measurements, cellularity and protein electrophoresis. Punctures were performed at the suboccipital levels in all patients.

Tomography (CT): decrease of the number and/or size of cysts, edema, hydrocephalus and the increase or appearance of the number of calcifications.

Patients were also further classified as having the benign, moderate or serious form of the disease. Benign cases were considered to be those patients who did not present hydrocephalus, alterations in conscience, or localizing neurological signs and who had no intracranial hypertension or only benign intracranial hypertension, headache and/or dizziness with pyramidal liberation. Moderately ill patients were those who presented convulsive seizures of difficult control, who progressed to a condition of "status epilepticus" or who had localizing neurological signs, meningitis or meningoencephalitis. Serious cases were those of patients presenting hydrocephalus or serious intracranial hypertension, or disturbances of conscience associated or not with localizing neurological signs. Among these were two patients with multiple racemose cysticercosis.

The results are showed in table 1.

Of the $\mathbf{4 0}$ patients with neurocysticercosis treated with albendazole, $32(80.0 \%)$ improved, whereas $4(10.0 \%)$ remained unchanged, and $4(10.0 \%)$ died. Of the four patients who died, two had racemose cysticercosis. The tomographic alterations were observed after an average of 6 months after the end of treatment in 23 of the 40 patients (Figure 1).

The best results in terms of neurological manifestations were observed in patients with benign and moderate forms of cysticercosis, i.e. those patients who showed epileptic syndrom, benign intracranial hypertension, headache and/or dizziness with pyramidal liberation, meningitis or meningoencephalitis.

The results reported by the various authors who used praziquantel in the treatment of cysticercosis are not uniform $1,3,9$. It should be pointed out that neurocysticercosis is frequent in the rural zone in Brazil, where it mainly attarks low socioeconomic-level individuals who have difficulty in acquiring this drug because of its high cost.

The combination of albendazole and dextrochloropheniramine seems to represent a valuable alternative treatment option. We emphasize that each case should be analyzed individually in terms of surgical procedures, symptom-relieving medication and specific chemotherapy, and the possibility of relapses are high for patients who continue to live under the same precarious hygiene conditions.

TABLE 1

Percentage of satisfactory results from neurological manifestation, quality of life CT scan and CSF analysis, according to the treatment groups.

\begin{tabular}{|c|c|c|c|c|c|}
\hline & $\begin{array}{c}\text { Patients } \\
\text { (No) }\end{array}$ & $\begin{array}{c}\text { Neurological } \\
\text { manifestation }\end{array}$ & $\begin{array}{l}\text { Quality } \\
\text { of life }\end{array}$ & CT scan & $\mathrm{CSF}$ \\
\hline Group I & 8 & $50.0 \%$ & $62.5 \%$ & $71.4 \%$ & $41.1 \%$ \\
\hline Group II & 13 & $83.3 \%$ & $75.0 \%$ & $71.4 \%$ & $54.9 \%$ \\
\hline Group III & 19 & $94.7 \%$ & $94.7 \%$ & $77.8 \%$ & $60.3 \%$ \\
\hline
\end{tabular}


AGAPEJEV, S.; MEIRA, D.A.; BARRAVIERA, B.; MACHADO, J.M.; PEREIRA, P.C.M.; MENDES, R.P.; KAMEGASAWA, A. \& CURI, P.R. - Neurocysticercosis: (reatment with albendazole and dextrochloropheniramine. (Preliminary report). Rev. Inst. Med. trop. São Paulo, 30(5):387-389, 1988
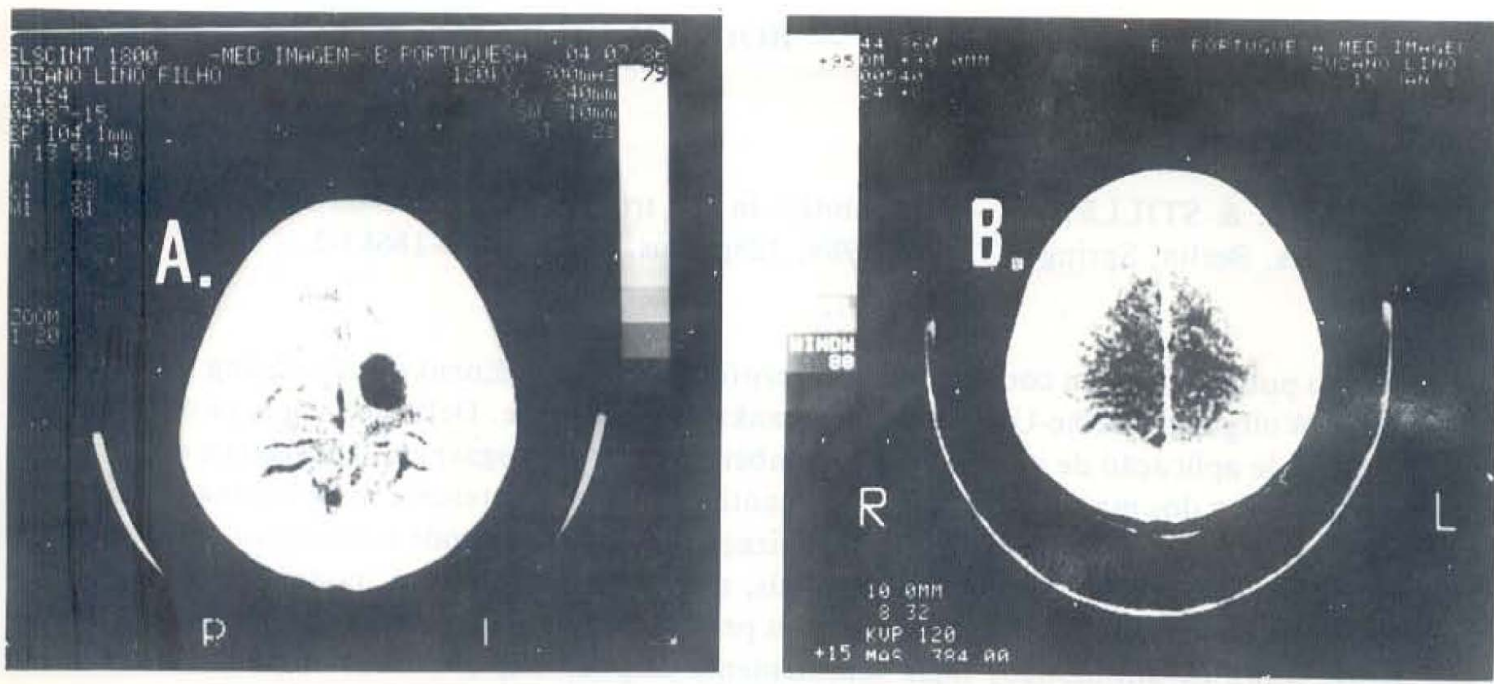

Figure 1 - Computadorized axial tomography of the skull, with contrası, in a patient with cysticercosis of moderate severity belonging to Group III and treated with a combination of albendazole and dextrochloropheniramine.

A. giant solitary cyst in the left parietal region surrounded by slight edema observed before treatment.

B. marked reduction of the cyst 45 days after the end of treatment.

\section{REFERENCES}

1. BOTERO, D.R. \& CASTAÑO, S. - Treatment of cysticercosis with praziquantel in Colombia. Amer.J. trop. Med. Hyg., 31:811-821, 1982.

2. BROWNSTEIN, M.J. - Serotonin, histamine and the purines. In: SIEGEL, G.J.; ALBERS, R.W.; AGRANOFF, B.W. \& KATZMAN, R., ed. - Basic neurochemistry. $3^{\text {rd }}$. ed. Boston, Little, Brown and Co. 1982. p.219-231

3. FLISSER, A; WILLMS, K; LACLETTE, J.P.; LARRALDE, C.; RIDAURA, C. \& BELTRAN, F., ed. - Cysticercosis: present state of knowledge and perspectives. New York, Academic Press, 1982. 700p.

4. GEMMELL, M.; MATYAS, Z.; PAWLOWSKI, Z; SOULSBY, E.J.L. in cooperation with LARRALDE, C.; NELSON, G.S.; ROSICKY, B. \& WORLD HEALTH ORGANIZATION (W.H.O) — Guidelines for surveillance, prevention and control of Taeniasis/Cysticercosis. Geneva, W.H.O., 1983.p.207. 5. GILMAN, A.G.; GOODMAN, L.S.; RALL, T.W. \&
MURAD, F - Goodman and Gilman's. The pharmacological basis of therapeutics. $7^{\text {th }}$ ed. New York, Mac Millan, 1980. $1839 \mathrm{p}$

6. INTERNATIONAL SYMPOSIUM OF CYSTICERCOSIS. J. bras. Med., 45 (suppl. May): 1-101, 1982.

7. MORRIS, D.L.; DYKES, P.W.; MARRINER, S. BOGAN, J.; BURROWS, F.; SKEENE-SMITH, H. \& CLARKSON, M.J. - Albendazole: objective evidence of response in human hydatid disease. J. Amer. med. Ass., 253:2053-2057, 1985.

8. PENE, P.; MOJON, M.; GARIN, J.P.; COULAND, J.P. \& ROSSIGNOL, J.F. - Albendazole: a new broad-spectrum antihelmintic. Double-blind multicenter clinical trial. Amer. J. trop. Med. Hyg., 31:263-266, 1982.

9. ROBLES, C.; SEDANO, A.M.; VARGASTENTORI, N. \& GALINDO-VIRGEN, S. - Longterm results of praziquantel therapy in neurocysticercosis. J. Neurosurg., 66:359-363, 1987.

Recebido para publicação em 20/3/1988. 